\title{
Controlling Lyngbya wollei in three Alabama, USA reservoirs: summary of a long-term management program
}

\author{
Wesley T. Anderson ${ }^{1} \cdot$ Josh N. Yerby ${ }^{1} \cdot$ Jason Carlee ${ }^{1} \cdot$ West M. Bishop $^{2}(1) \cdot$ Ben E. Willis $^{2} \cdot$ C. Todd Horton ${ }^{3}$
}

Received: 29 March 2019 / Accepted: 3 October 2019 / Published online: 14 October 2019

(c) The Author(s) 2019

\begin{abstract}
Large-scale Lyngbya wollei (Cyanobacteria, Oscillatoriales) infestations are increasing throughout the USA and globally and causing significant obstruction of water resource uses. Decision makers and stakeholders encountering this nuisance organism often seek management options. Many approaches to L. wollei management may be ineffective or not applicable to specific field sites. Chemical control with United States Environmental Protection Agency registered algaecides has shown to be effective, although the specific formulation, concentration, and application frequency can all govern efficacy. This study summarizes results from a long-term and adaptive management program on extensive $L$. wollei infestations in three central Alabama, USA reservoirs (Lay Lake, Jordan Lake and Lake Mitchell) managed by Alabama Power Company. Multiple treatment strategies including numerous algaecides, combinations and addition of surfactants were used in attempts to control the nuisance cyanobacterium and preserve multiple beneficial functions of the resource. Ultimately, operational shift toward one technology, a double-chelated copper algaecide with surfactants and emulsifiers (Captain ${ }^{\circledR}$ XTR) resulted in more efficient and economical control. There were significant $(P<0.05)$ decreases in historic $L$. wollei acres requiring treatment through time on each reservoir. Throughout this study period, a 51.4, 88.1 and $94.7 \%$ percent decrease in total nuisance acres treated was realized on Lay Lake, Jordan Lake and Lake Mitchell, respectively. The large-scale and long-term dataset presented herein, covering multiple candidate treatment programs, provides valuable information to guide management decisions on other water resources impacted by $L$. wolle $i$ infestations.
\end{abstract}

Keywords Lyngbya wollei $\cdot$ Cyanobacteria $\cdot$ Management $\cdot$ Algaecide $\cdot$ Copper

\section{Introduction}

Lyngbya wollei Farlow ex Gomont (Speziale and Dyck 1992 [syn Microseira wollei]) is a filamentous cyanobacterium that can achieve substantial biomass in freshwater resources and is proliferating in many areas throughout the USA (Bridgeman and Penamon 2010; Hudon et al. 2014). Growth forms include benthic, suspended and floating mats which impede critical water resource uses (e.g., power generation, wildlife habitat, recreation, property values)

West M. Bishop

westb@sepro.com

1 Alabama Power Company, 744 Co Rd 87, Calera, AL 35040, USA

2 SePRO Research and Technology Campus, 16013 Watson Seed Farm Rd., Whitakers, NC 27891, USA

3 SePRO Corporation, Anderson, SC 29624, USA and can harbor pathogenic fecal bacteria (Vijayavel et al. 2013). L. wollei has been documented to produce numerous toxins that can negatively impact irrigated crops, livestock, wildlife and humans (Foss et al. 2012; Bhadha et al. 2014; Paerl et al. 2016). In large, multi-use reservoirs, disruption of critical water uses often requires implementation of management, although management initiatives must be in line with water use objectives. Multiple approaches (e.g., mechanical, biological, chemical, cultural) to $L$. wollei management are often considered. With dynamic nature (e.g., depth, location, access, terrain) of many of the typical infested sites, mechanical control is unlikely an effective option and requires dedicated personnel and maintenance (Calomeni et al. 2015). Biological control measures have not been shown to be a viable option for large-scale management of this species. Despite some anecdotal reports of elevated grass carp densities consuming $L$. wollei, it has been shown in numerous studies not to be preferred food source (Dyck 1994; Kasinak et al. 2015), and that carp can alter ecosystem 
functionality and negatively impact overall water quality (Dibble and Kovalenko 2009). Due to potential for efficacy and rapid ability to show results, United States Environmental Protection Agency (USEPA)-registered algaecides are a critical component of $L$. wollei management. Efficiency of algaecides and application programs can differ significantly (Bishop and Rodgers 2012; Bishop et al. 2018a). Selecting the most effective program is critical for achieving management objectives while decreasing costs, environmental load and operational inputs (Bishop and Rodgers 2011). Algaecide treatments can be implemented successfully for L. wollei infestations (Bishop et al. 2015), although successful management requires an increased understanding of exposure characteristics and temporal aspects of controlling large infestations.

The large mat structure formed by $L$. wollei is innately less responsive to many chemical control techniques (Lembi 2000). Thick mats restrict contact of applied algaecides to filaments in deeper mat layers. Visual reports suggest only the uppermost layer of the mat may show symptoms to algaecides, whereas lower layers appear uninjured and allow for continued growth. The large mucilaginous sheath (up to $60 \%$ of dry biomass), covering the multicell trichome, is comprised of homoglucan and cross-linked monosaccharides (Hoiczyk 1998). The sheath, in part, can provide resilience to chemical control measures (Tien et al. 2005) as has allowed growth in environments with elevated contaminants (Reynolds 2007). Even with effective treatment programs that result in non-viable $L$. wollei, the cellular structure often remains intact and not easily degraded (i.e., dead $L$. wolle $i$ possesses a similar biomass to living). It often takes months or years to discern biomass changes of $L$. wolle $i$ mats in field management scenarios due to heterogeneity, thickness and mobility potential. Tien et al. (2005) found that dead cells can sorb copper and may interfere with effectiveness of subsequent algaecide applications. Multiple treatments annually and long-term assessments allow the ability to distinguish results of management programs through time. This incorporates both the progression of non-viable material degradation along with contained control of new biomass, assuming the program is effective. Additionally, potential increased biomass from growth of viable biomass may be observed with ineffective management programs. The viability of the biomass can be used to assess the efficacy of short-term programs (Bishop et al. 2015). Although biomass alone often requires significant time to manifest as a response parameter, it is important to assess as dead biomass can impede utilization of water resources similar to live biomass.

In accordance with the critical burden concept, a specific amount of a USEPA-approved algaecide is predicted to only control a specific biomass of L. wollei (Bishop and Rodgers 2012; Bishop et al. 2018a). With dense infestations, a single application of any current registered algaecide at the maximum label rate is unlikely to achieve control of the entire $L$. wolle $i$ biomass; therefore, the presence of viable biomass will persist. A regimented control program to stepwise reduce biomass through time is often required. Significant differences in algaecide formulations, including those with similar listed active ingredients, have been documented (Bishop et al. 2018a). Chelated copper-based algaecides are common components of $L$. wollei management programs and are often combined with surfactants to aid penetration (Duke 2007; Bishop et al. 2015; Calomeni et al. 2015). The chelation is designed to improve stability of the copper ion in solution and alter charge properties of resulting copper complexes to passively penetrate cell membranes (Stauber and Florence 1987; Straus and Tucker 1993; Mastin and Rodgers 2000). Analyzing results of long-term management programs allows comparison of algaecide formulation efficiency at attaining control and achieving management objectives toward selecting an efficacious product for largescale management.

The advent of large-scale $L$. wollei infestations in Alabama Power Company managed reservoirs (i.e., Lay Lake, Jordan Lake, Lake Mitchell) significantly threatened the ecological function, economic value and overall utilization of these systems. Critical functions of these systems include recreational activities (e.g., fishing, swimming, boating), economic impact (property values, aesthetics, tourism), anthropogenic uses (potable water source, industrial, irrigation) as well as wildlife habitat (including endangered species). Regimented algaecide applications, often $>5$ applications per year, have been used to target infested areas of these systems for over two decades (Iwinski et al. 2016). Multiple algaecide treatment programs have been researched and utilized in Lay Lake, Jordan Lake and Lake Mitchell with the goal of decreasing $L$. wollei biomass to preserve management objectives (Duke 2007; Tedrow 2007; Bishop et al. 2015; Calomeni et al. 2015). The overall goal of this research was to summarize the primary treatment programs utilized in Alabama Power Company reservoirs as well as resultant effectiveness through time. As L. wollei infestations are common throughout the southeastern United States (Speziale and Dyck 1992; Regan et al. 2017) and continue to spread, especially through the Laurentian Great Lakes basin (Bridgeman and Penamon 2010; Vijayavel et al. 2013), long-term datasets covering multiple candidate treatment programs can be extremely valuable to guide management decisions in different sites.

Specific objectives of this study were to (1) summarize approaches to management of $L$. wollei in three central Alabama reservoirs (Lay Lake, Jordan Lake and Lake Mitchell); (2) compare the effectiveness of different algaecide treatment programs for controlling $L$. wollei based on the change in acres treated through time; (3) assess parameters leading to alterations in management programs. 


\section{Methods}

\section{Site description}

Three man-made reservoirs impounded along the Coosa River in central Alabama, USA, that received historic algaecide treatments for widespread $L$. wollei infestations were selected for this study (Fig. 1). Lay Lake, 12,108 surface acres (4900 ha), was built in 1914 and is located within St. Clair, Talladega, Shelby, Coosa and Chilton Counties; Jordan Lake, 6800 surface acres (2752 ha), built in 1928 is in Elmore County; and Lake Mitchell, 5859 surface acres (2371 ha), built in 1922 is located in Chilton and Coosa Counties. Infestations of $L$. wolle $i$ were located throughout all reservoirs. Mats often formed on the bottom of the reservoir and proceeded to move through the water column and form aggregated surface mat accumulations later in the year. Infestations were typically found in localized cove and/or shoreline areas of these dendritic reservoirs and growing to depths of up to $5 \mathrm{~m}$. Treatment sites were selected based on notable mats of $L$. wolle $i$ present in the majority of the treatment area. Treatment areas ranged from 0.25 to 16.5 acres in size with a mean of 1.35 surface acres (0.55 ha).
Fig. 1 Map and location of the three central Alabama reservoirs evaluated in this study

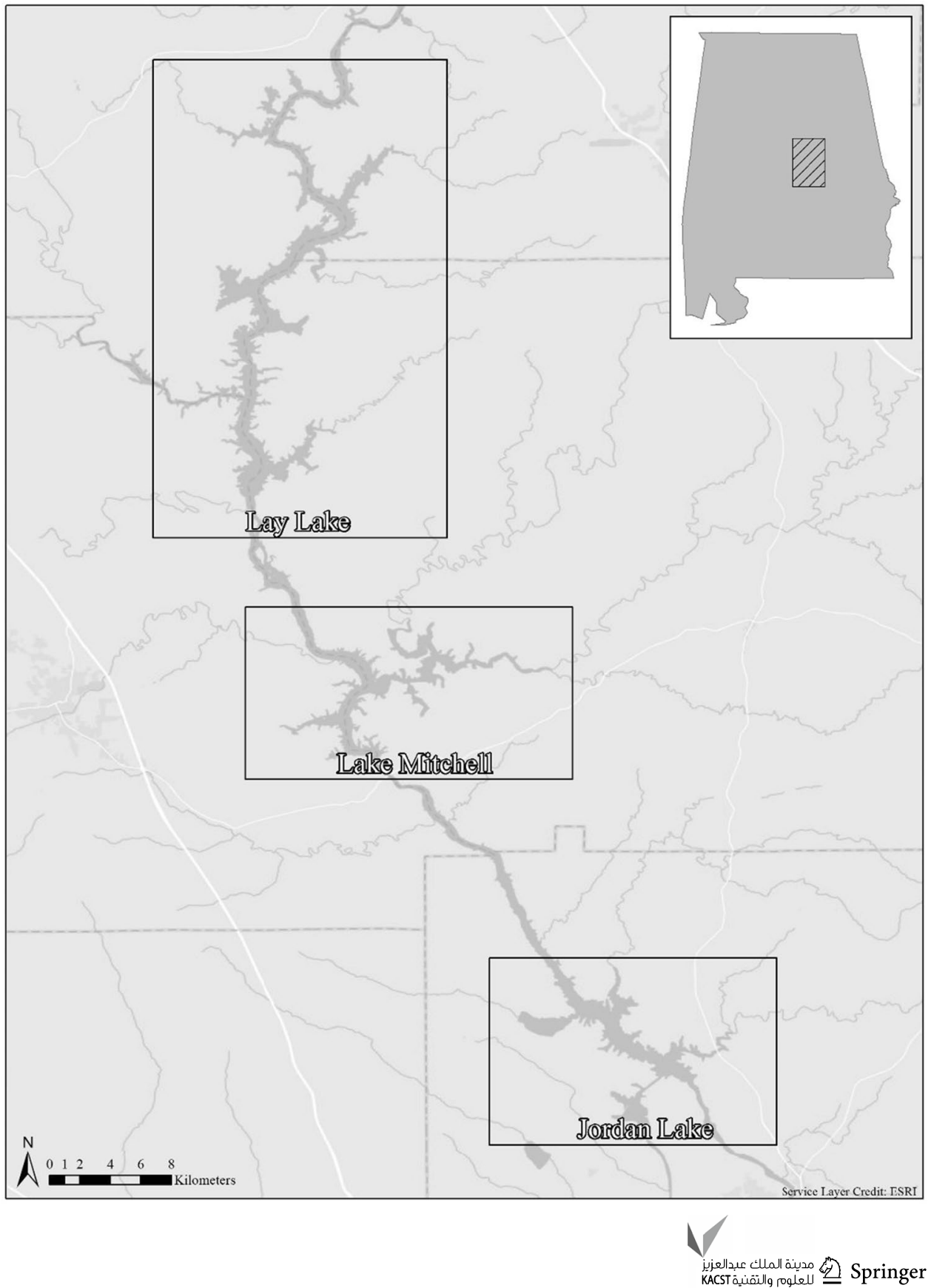




\section{Data acquisition}

Detailed records of algaecide and application costs were kept annually regarding $L$. wollei management. Records of product costs, contract application costs and internal application costs (if applicable) were maintained by the Environmental Affairs Department of Alabama Power Company. Annual inputs since 2013 for $L$. wollei management were compiled to use in this study assessment, although regular applications have occurred for over 20 years.

\section{Algaecide treatment programs}

Numerous USEPA-registered algaecides, approved for use in lakes and reservoirs, were primarily used to control L. wollei infestations in the three reservoirs. Product combinations, sequential applications and addition of approved aquatic surfactants were a component of many management programs. A list and description of the algaecides utilized in treatment programs over the last 6 years are presented in Table 1. Application of the algaecides was conducted by state-certified aquatic applicators and followed all label, shipping and regulatory requirements. Most applications were contracted with the professionals at Aqua Services, Inc. Treatment programs primarily consisted of five applications per year to each treated site. Note that in some years additional treatment sites were added later in the year and thus received less than five annual treatments. A GPS-guided application system was used to ensure good coverage and targeted algaecide amounts throughout the specific treatment area. With liquid applications, appropriate amounts of algaecide were placed in a 200-gallon tank and applied via subsurface injection to target benthic mats. A patented HD AQUA ${ }^{\circledR}$ system designed by Aqua Services, Inc. was used to inject a course spray of the product to the bottom contour of the

Table 1 Comparison of physical and chemical properties of the primary algaecide formulations tested in attempts to control $L$. wollei

\begin{tabular}{|c|c|c|c|c|c|c|}
\hline & Captain $^{\circledR}$ XTR $^{\mathrm{a}, \mathrm{b}}$ & Cutrine ${ }^{\circledR}$ Ultra $^{\mathrm{c}}$ & $\begin{array}{l}\text { Algimycin }^{\circledR}{ }_{-} \\
\mathrm{PWF}^{\mathrm{d}, \mathrm{e}}\end{array}$ & $\begin{array}{l}\text { Phycomycin }^{\circledR} \text { - } \\
\text { SCP }^{f}\end{array}$ & $\begin{array}{l}\text { Green Clean }{ }^{\circledR} \\
\text { Liquid } 2.0^{\mathrm{g}, \mathrm{h}}\end{array}$ & Hydrothol $^{\circledR} 191^{\mathrm{i}, \mathrm{j}}$ \\
\hline Manufacturer & $\begin{array}{l}\text { SePRO Corpora- } \\
\text { tion }\end{array}$ & $\begin{array}{l}\text { Applied Biochem- } \\
\text { ists }\end{array}$ & $\begin{array}{l}\text { Applied Biochem- } \\
\text { ists }\end{array}$ & $\begin{array}{l}\text { Applied Biochem- } \\
\text { ists }\end{array}$ & $\begin{array}{l}\text { BioSafe Systems, } \\
\text { LLC }\end{array}$ & UPL NA, Inc. \\
\hline $\begin{array}{l}\text { Identification } \\
\text { (EPA Reg. No.) }\end{array}$ & $67690-9$ & $8959-53$ & $7364-9-8959$ & $68660-9-8959$ & $70299-12$ & $70506-175$ \\
\hline $\begin{array}{l}\text { Active Ingredient } \\
\text { (formulation) }\end{array}$ & $\begin{array}{l}\text { Copper-ethanola- } \\
\text { mine complexes } \\
\text { (SP9000 sur- } \\
\text { factants) }\end{array}$ & $\begin{array}{l}\text { Copper-ethanola- } \\
\text { mine complexes } \\
\text { (D-limonene) }\end{array}$ & $\begin{array}{l}\text { Chelates of cop- } \\
\text { per citrate and } \\
\text { gluconate }\end{array}$ & $\begin{array}{c}\text { Sodium carbonate } \\
\text { peroxyhydrate }\end{array}$ & $\begin{array}{l}\text { Hydrogen dioxide/ } \\
\text { Peroxyacetic } \\
\text { acid }\end{array}$ & $\begin{array}{l}\operatorname{Mono}(N, N- \\
\text { dimethyla- } \\
\text { lkylamine) salt } \\
\text { of endothall }\end{array}$ \\
\hline $\begin{array}{l}\% \text { Active Ingredi- } \\
\text { ent complex }\end{array}$ & 28.2 & 27.8 & 25.4 & 85 & $27.1 / 2$ & 53 \\
\hline Chelator amount & $\begin{array}{l}\text { Triethanolamine } \\
\text { complex-14.9\% } \\
\text { Monoethanolamine } \\
\text { complex-13.3\% }\end{array}$ & $\begin{array}{l}\text { Triethanola- } \\
\text { mine-20-30\% } \\
\text { Ethanola- } \\
\text { mine-18-28\% }\end{array}$ & $\begin{array}{l}\text { Chelates of copper } \\
\text { gluconate } 12.5 \% \\
\text { Chelates of copper } \\
\text { citrate } 12.9 \%\end{array}$ & NA & NA & NA \\
\hline Appearance & Blue viscous liquid & Blue viscous liquid & Blue liquid & $\begin{array}{l}\text { White, granular } \\
\text { solid }\end{array}$ & $\begin{array}{l}\text { Clear, colorless } \\
\text { liquid }\end{array}$ & $\begin{array}{c}\text { Dark yellow light } \\
\text { brown liquid }\end{array}$ \\
\hline Water solubility & Miscible & Miscible & Miscible & $140 \mathrm{~g} / \mathrm{L}(20 \mathrm{C})$ & Soluble & Soluble \\
\hline $\mathrm{pH}(\mathrm{SU})$ & $10-10.5$ & $10.2-10.3$ & $1.5-2.5$ & $\begin{array}{l}10.4-10.6(3 \% \\
\text { solution) }\end{array}$ & 0.96 & Not listed \\
\hline $\begin{array}{l}\text { Specific Gravity } \\
\left(\mathrm{g} / \mathrm{cm}^{3}\right)\end{array}$ & 1.2 & $\sim 1.2$ & $\sim 1.2$ & $0.9-1.2$ & 1.1 & $1.044(25 \mathrm{C})$ \\
\hline
\end{tabular}

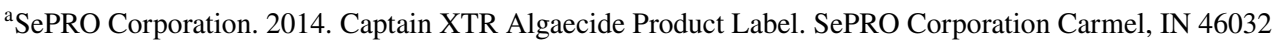

${ }^{\mathrm{b}}$ SePRO Corporation. 2018. Captain XTR Algaecide Safety Data Sheet. SePRO Corporation Carmel, IN 46032

${ }^{\mathrm{c}}$ Applied Biochemists. 2015. Cutrine Ultra Algaecide Safety Data Sheet. Applied Biochemists Inc. Germantown, WI 53022

${ }^{\mathrm{d}}$ Applied Biochemists. 2010. Algimycin PWF Algaecide Safety Data Sheet. Applied Biochemists Inc. Germantown, WI 53022

${ }^{\mathrm{e}}$ Applied Biochemists. 2014. Algimycin PWF Algaecide label. Applied Biochemists Inc. Germantown, WI 53022

${ }^{\mathrm{f}}$ Applied Biochemists. 2015. Phycomycin Algaecide and Oxidizer Safety Data Sheet. Applied Biochemists Inc. Germantown, WI 53022

${ }^{\mathrm{g}}$ BioSafe Systems LLC. Green Clean Liquid 2.0 Safety Data Sheet. East Hartford, CT 06108

${ }^{\mathrm{h}}$ BioSafe Systems LLC. Green Clean Liquid 2.0 Product label. East Hartford, CT 06108

${ }^{i}$ UPL. 2017. Hydrothol 191 Aquatic Algaecide and Herbicide Product Label. UPL NA, Inc. King of Prussia, PA 19406

${ }^{j}$ UPL. 2018. Hydrothol 191 Aquatic Algaecide and Herbicide Safety Data Sheet. UPL NA, Inc. King of Prussia, PA 19406 
treatment site to promote increased algaecide interaction with benthic mats. This system automatically accounted for changes in depth profiles and hydraulically raised and lowered the spray boom to maintain a consistent injection of the product near the bottom $(\sim 0.3 \mathrm{~m})$ of the site. In shallow water $(<0.6 \mathrm{~m})$, where it was difficult to get good contact with injection applications, surface spray applications were additionally conducted starting in 2013. Annual treatments typically started in April after the water temperatures increased $(\sim 18 \mathrm{C})$, although in one winter (December 2013-February 2014) additional earlier season treatments were conducted to more dormant $L$. wollei to evaluate whether results improved. An overview of each treatment program is outlined below, and more details are summarized in Table 2.

\section{Program 1}

Phycomycin ${ }^{\circledR}$-SCP was applied $\sim 24 \mathrm{~h}$ preceding Algimycin ${ }^{\circledR}$-PWF combined with the surfactant CideKick $^{\circledR}$ II. Products had to be applied on separate days to avoid large $\mathrm{pH}$ swings in a short time period. Phycomycin SCP was injected into the water column to promote interaction with benthic mats. The follow-up application of Algimycin PWF was combined with Cide-Kick II in the spray tank setup described above.

\section{Program 2}

Green Clean ${ }^{\circledR}$ Liquid 2.0 and Hydrothol ${ }^{\circledR} 191$ were combined in a single tank mix with water to target $L$. wolle $i$ mats. Anecdotal reports of additive or synergistic impacts warranted evaluation of this approach.

\section{Program 3}

Cutrine ${ }^{\circledR}$ Ultra was used alone as well as with an additional surfactant, Cygnet ${ }^{\circledR}$ Plus. These were pooled together under this single program designation for analysis purposes. The Cutrine formulations (Plus and Ultra) were also the primary products that had been historically used prior to 2008 .

\section{Program 4}

Phycomycin ${ }^{\circledR}$-SCP was applied $\sim 24$ h preceding Captain ${ }^{\circledR}$ XTR. This sequence was conducted to compare with Captain XTR alone to evaluate whether the added peroxide assisted with mat destruction or algaecide penetration to increase efficacy.

\section{Program 5}

Captain ${ }^{\circledR}$ XTR alone was used in this program. Algaecide was diluted in the spray tank or applied as concentrate. The high density of this product in the concentrate spray solution may have allowed increased interaction on benthic mats.

Table 2 Description of $L$. wollei treatment programs used on the three Alabama reservoirs from 2013 to 2018

\begin{tabular}{|c|c|c|c|c|c|}
\hline $\begin{array}{l}\text { Program } \\
\text { designa- } \\
\text { tion }\end{array}$ & Program products & $\begin{array}{l}\text { Product applied per } \\
\text { treated surface acre }\end{array}$ & $\begin{array}{l}\text { Max amount of product } \\
\text { applied per year (all } \\
\text { reservoirs) }\end{array}$ & $\begin{array}{l}\text { Relative chemical } \\
\text { and application } \\
\text { costs }^{\mathrm{a}}\end{array}$ & Notes \\
\hline 1 & $\begin{array}{l}\text { Phycomycin } \\
\text { SCP => Algimycin } \\
\text { PWF + Cide-Kick II }\end{array}$ & $45-105 \mathrm{lb}=>11-26$ gall & $44,207 \mathrm{lb}=>11,079$ gall & High & $\begin{array}{l}\text { Two separate applications } \\
\text { pH alterations } \\
\text { Ecotoxicity } \\
\text { Mat displacement } \\
\text { Oxidizer } \\
\text { PPE }\end{array}$ \\
\hline 2 & $\begin{array}{l}\text { Hydrothol } 191+\text { Green } \\
\text { clean liquid (granular } \\
\text { in 2014) }\end{array}$ & $\begin{array}{l}0.49- \\
\quad 1.8 \text { gall }+1.33-5 \text { gall }\end{array}$ & 991 gall + 3331 gall & High & $\begin{array}{l}\text { Two separate products } \\
\text { Ecotoxicity } \\
\text { Oxidizer } \\
\text { PPE }\end{array}$ \\
\hline 3 & $\begin{array}{l}\text { Cutrine ultra } \pm \text { Cygnet } \\
\text { plus }\end{array}$ & 19-22 gall & 128 gall +8.5 gall & Moderate & $\begin{array}{l}\text { Historic use } \\
\text { Ecotoxicity } \\
\text { PPE }\end{array}$ \\
\hline 4 & $\begin{array}{l}\text { Phycomycin SCP => Cap- } \\
\text { tain XTR }\end{array}$ & $95-100 \mathrm{lb}=>14-15$ gall & $22,487 \mathrm{lbs}=>3373$ gall & High & $\begin{array}{l}\text { Two separate applications } \\
\text { Mat displacement } \\
\text { Oxidizer } \\
\text { PPE }\end{array}$ \\
\hline 5 & Captain XTR alone & $6-17.5$ gall & 7727 gall & Moderate & $\begin{array}{l}\text { Single product } \\
\text { PPE }\end{array}$ \\
\hline
\end{tabular}

${ }^{\text {a} A d d i t i o n a l ~ i n f o r m a t i o n ~ a v a i l a b l e ~ u p o n ~ r e q u e s t ~}$ 


\section{Data analysis}

All treatments sites were surveyed periodically throughout treatments, especially at the start and end of treatment programs. Visual assessments, including benthic rake tosses, were used to assess whether prior treatment sites required more treatments the same year or subsequent years. In later years, ciBioBase ${ }^{\circledR}$ imagery from a Lowrance ${ }^{\mathrm{TM}}$ depth finders was also utilized to visualize the presence of benthic mats. The decision to add/maintain a treatment site for a given year was based on the presence of a notable $\left(\sim 200 \mathrm{~g} \mathrm{ww} / \mathrm{m}^{2}\right)$ biomass of $L$. wollei in collected samples from that plot. Some plots were added back into treatment programs mid-season if notable increase in $L$. wol$l e i$ was found post-initial sampling. Percent decreases in acres treated each year on each reservoir were calculated by dividing acres treated in a given year by initial acres at the start of this summary (2013). Regression analyses were conducted on percent decrease in acres treated through time on each reservoir to assess whether significant $(\alpha=0.05)$ correlations existed. Since new acres, not previously treated, were added on Lay Lake in 2017/2018, these were excluded from this analysis. All analyses and graphs were performed using Microsoft Excel (Microsoft 2010).

\section{Results and discussion}

\section{Shift in algaecide treatment programs}

Algaecide treatment programs prior to this study period primarily utilized Cutrine Plus and Cutrine Ultra. Marginal results, which at most produced growth suppression, were seen from these treatment programs with similar acres requiring applications annually. Numerous university-based laboratory bioassays were conducted to compare efficacy of different treatment programs (Duke 2007; Tedrow 2007). The program developed through this research (Program 1 outlined above) was also used for many years, starting in 2008, with variable results. In 2013, this program was implemented on $\sim 50 \%$ of the targeted $L$. wollei treatment acreage. Most other acres treated in 2013 year utilized Program 2, which included a combination of two products in a single tank mix and an active ingredient not previously applied (Figs. 2, 3, 4). Additionally, in attempts to continue to optimize treatment programs, Alabama Power Company also evaluated a newly registered product in Lay Lake (Program 5; Captain XTR) which later received a patent on the unique formulation design (Ullah et al. 2015). Starting midway through the 2013 application season, Program 5 was implemented on a limited number of acres.
Fig. 2 Surface acres of nuisance L. wollei infestations treated with each algaecide treatment program in Lay Lake through time

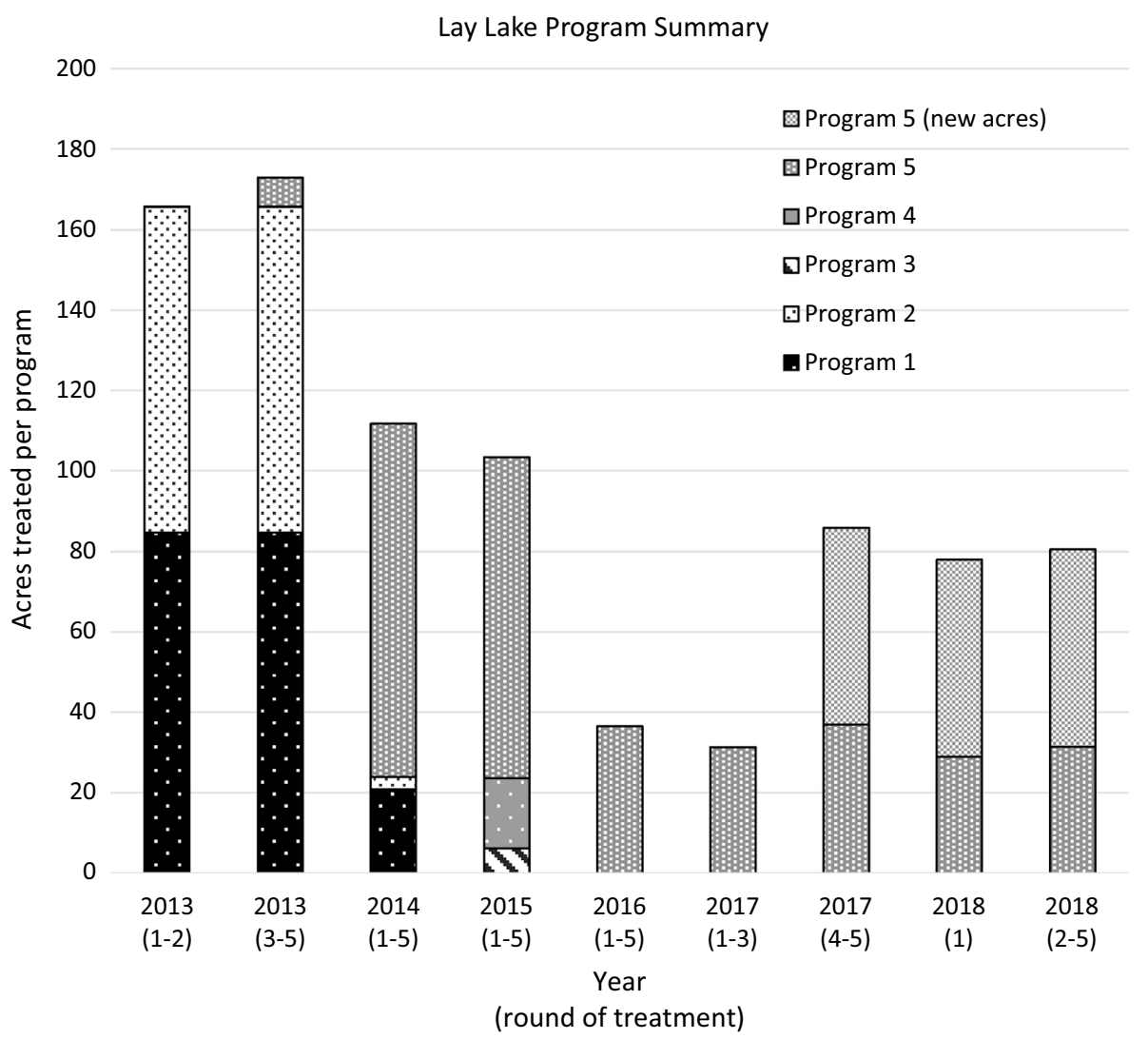


Fig. 3 Surface acres of nuisance L. wollei infestations treated with each algaecide treatment program in Jordan Lake through time

Fig. 4 Surface acres of nuisance L. wollei infestations treated with each algaecide treatment program in Lake Mitchell through time
Jordan Lake Program Summary

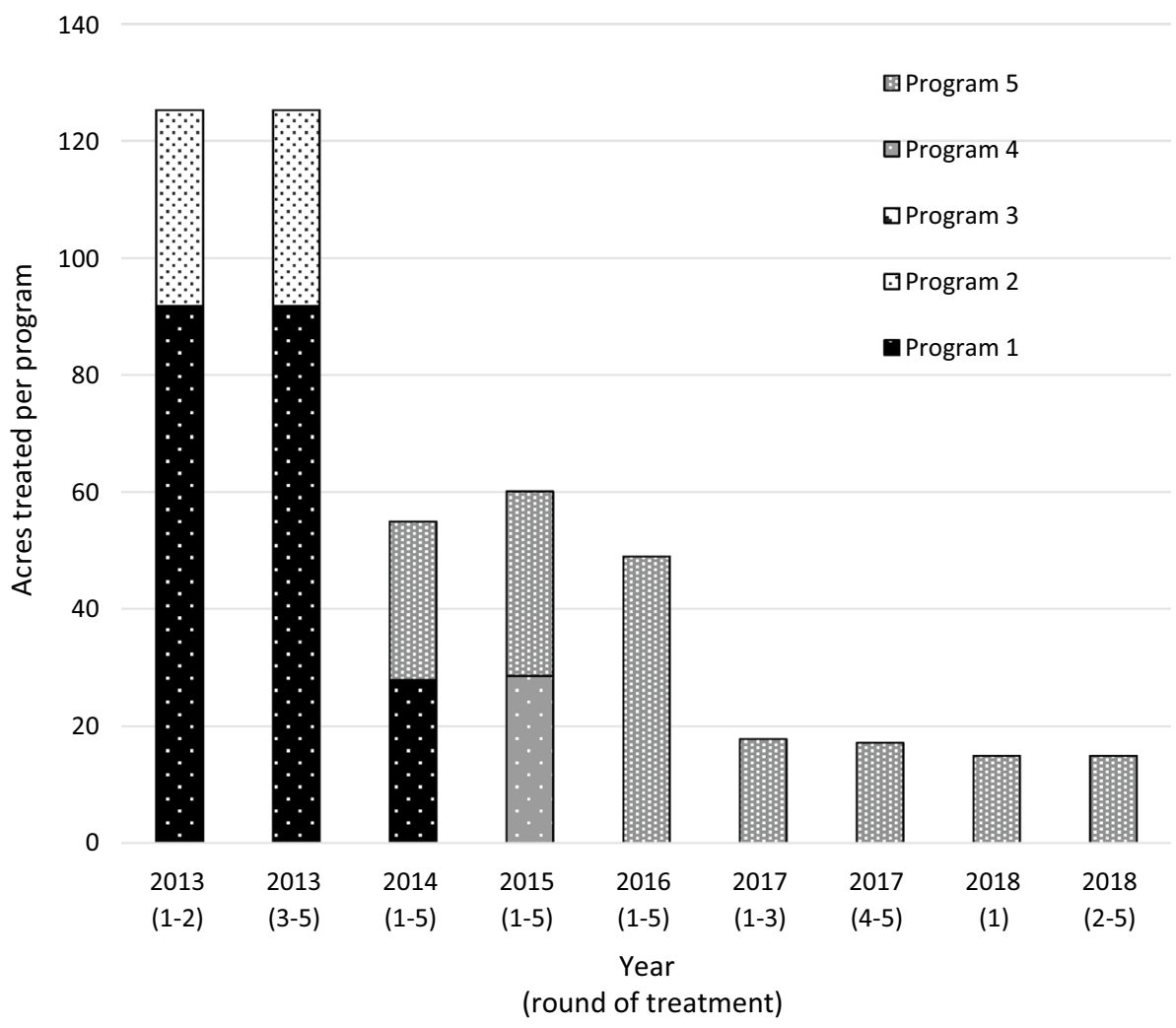

Lake Mitchell Program Summary

25

ㅁogrogram 5

口Program 4

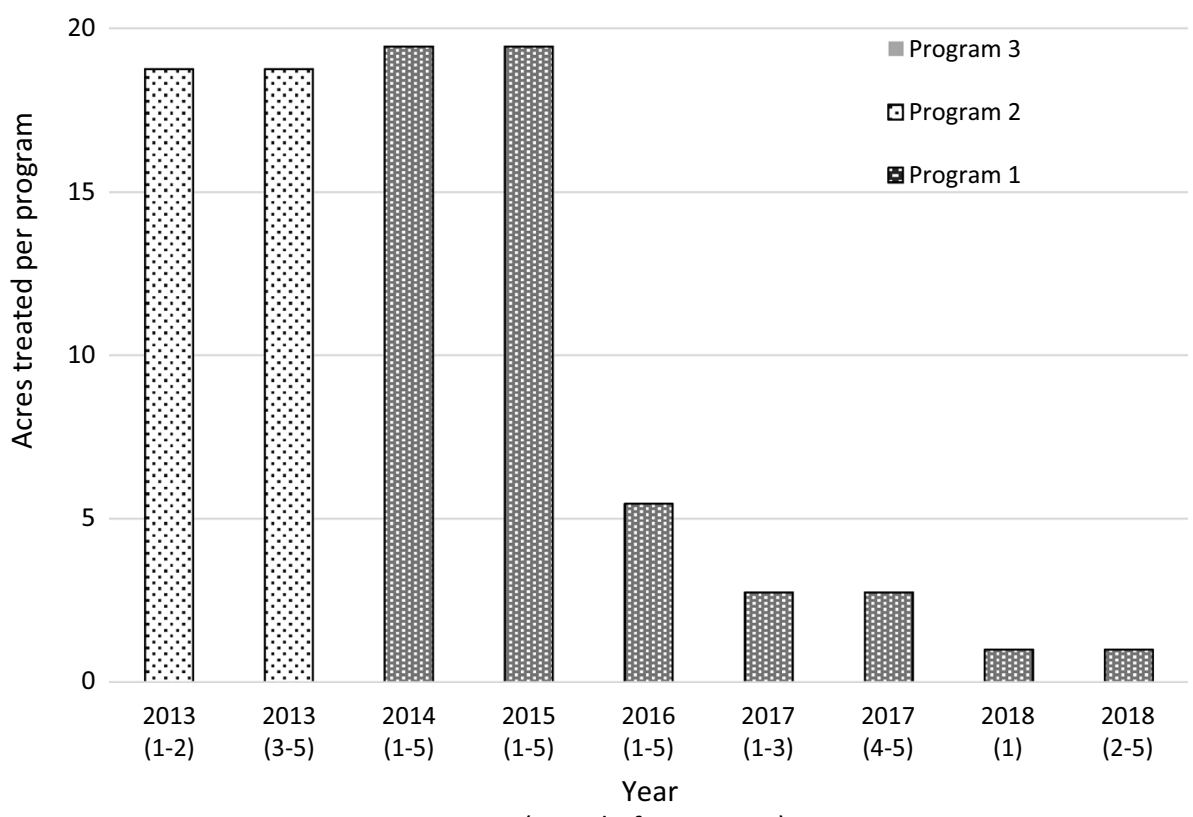

(round of treatment) 
The tests with Program 5 from 2013 yielded positive results, and the majority of the $L$. wollei treatment sites in 2014 were shifted to this treatment method. Costs for this product compared with the combination of products (Program 2) that it replaced were essentially equal. The applicators only had to transport and handle one product vs two, which resulted in improved application efficiency. This product also had less personal protective equipment (PPE) requirements than products used in the combination treatment (Program 2). In 2014, 26\% of the treatment acreage remained on Program 1. The remaining 74\% was treated using Program 5. One smaller scale plot remained with an altered version of Program 2, where the Green Clean Liquid was replaced with a larger granular formulation to target benthic mats. However, the difficulty of application and PPE requirements were deemed to be too great to integrate into future treatments. Alabama Power Company staff also continued research efforts with university students involving different algaecide treatments, and their effects on $L$. wolle $i$ sampled from Lay Lake. None of those additional treatment options tested by the university were effective enough to justify the increased cost associated with them and therefore not utilized in future programs.

Based on the promising results documented in sites managed with Program 5 from 2013 to 2014, all operational treatment sites were shifted to include Captain XTR, either alone (Program 5) or as a sequential treatment following Phycomycin SCP (Program 4). Additionally, in a continued effort to further explore and compare control options, Alabama Power Company staff assisted an algaecide manufacturer, in concert with a university, in evaluating test plots on Lay Lake using Cutrine ${ }^{\circledR}$ Ultra alone or tank mixed with an additional surfactant (Program 3). Based on the efficacy results attained by the university, these two methods were not effective enough to warrant further testing.

The end of season surveys from 2015 demonstrated the combination treatment (Program 4) was no more effective than the Captain XTR product alone (Program 5). Eliminating Phycomycin SCP from the treatment prescription also significantly reduced overall program costs by reducing product and labor expenses. Applicator efficiency also increased along with a decrease in logistics and risks associated with these two products versus one product. All reservoirs were therefore shifted to Captain ${ }^{\circledR}$ XTR alone (Program 5) by 2016. The ciBioBase mapping program was fully utilized in 2016, and average depths and total volume throughout treatment sites were better able to be estimated. This allowed optimization of the treatment strategy to achieve necessary exposures to attain control (Bishop et al. 2015).

Treatment site surveys in Spring 2017 demonstrated continued positive results from Program 5. Numerous sites with little or no growth were removed from the treatment list and placed on a monitor list. The remaining sites continued five annual applications using Program 5. Only two small sites (total $2.75 \mathrm{~A}$ ) remained on Lake Mitchell, and the decision was made to treat those with internal staff. Two remote sites (0.65 A total) on Lake Jordan were also treated in-house. After the third round of treatments in mid-summer, nine old sites showed re-growth on Lay Lake and were placed back on the contractors treatment list. Additionally, 17 new sites totaling 49 acres not previously treated were added to treatment sites. Each site was mapped with ciBioBase to determine average depths for herbicide rate calculations.

In 2018, consistent positive results were documented with Program 5 and this was again selected for use in all treatment sites. Site surveys on Mitchell Lake indicated little/ no growth and greatly decreased biomass of $L$. wollei, and the decision was made to only monitor these sites through 2018. The 2018 growing season was the warmest over the study period. Treatment acreage on Lay and Jordan reservoir was similar between 2018 and 2017, and one new site was added on Lay Lake after the first round of treatment. Treatment sites maintained the similar levels of biomass but never exhibited a significant reduction through five rounds. The high re-growth rates prior to subsequent treatments and high existing biomass were thought as responsible for this. Numerous homeowner requests were received for $L$. wolle $i$ treatments that were not included in the initial program acres due to the high growth in these untreated areas throughout 2018. These new requests were given one late season (August) treatment of Captain XTR by Alabama Power Company staff, and those sites will be surveyed to determine the necessity of adding them to the 2019 treatment program.

\section{Decrease in treated acres through time}

From 2013 to 2018, drastic decreases in total treated acres were measured for each reservoir (Fig. 5). The lowest level of treatment acres documented in Lay Lake (31.42) occurred at the beginning of 2017 and was an $81 \%$ decrease compared with initial acres in 2013. This was after 3 years of treatment primarily with Program 5. However, primarily due to addition of 17 new sites ( 49 acres) with nuisance $L$. wollei growth that had not previously been treated, treatment acres increased in later 2017 and 2018. Excluding these new acres, an $81 \%$ decrease in treated acres would have consistently been realized in Lay Lake in 2018. Including these acres, total treated acres were still down $51.4 \%$ in Lay Lake at the study completion compared with original acres targeted. In 2013, at the beginning of the study, Jordan lake had 125.26 surface acres in a $L$. wolle $i$ treatment program. After two seasons (2015-2016) with Captain XTR as a component of all treatment programs, Jordan Lake had an $86.3 \%$ decrease in acres requiring treatment in 2017 . There was a continued decrease in acres treated in 2018 (14.93 total), representing 
Fig. 5 Total surface acres treated for nuisance $L$. wolle $i$ infestations in three Alabama reservoirs through time

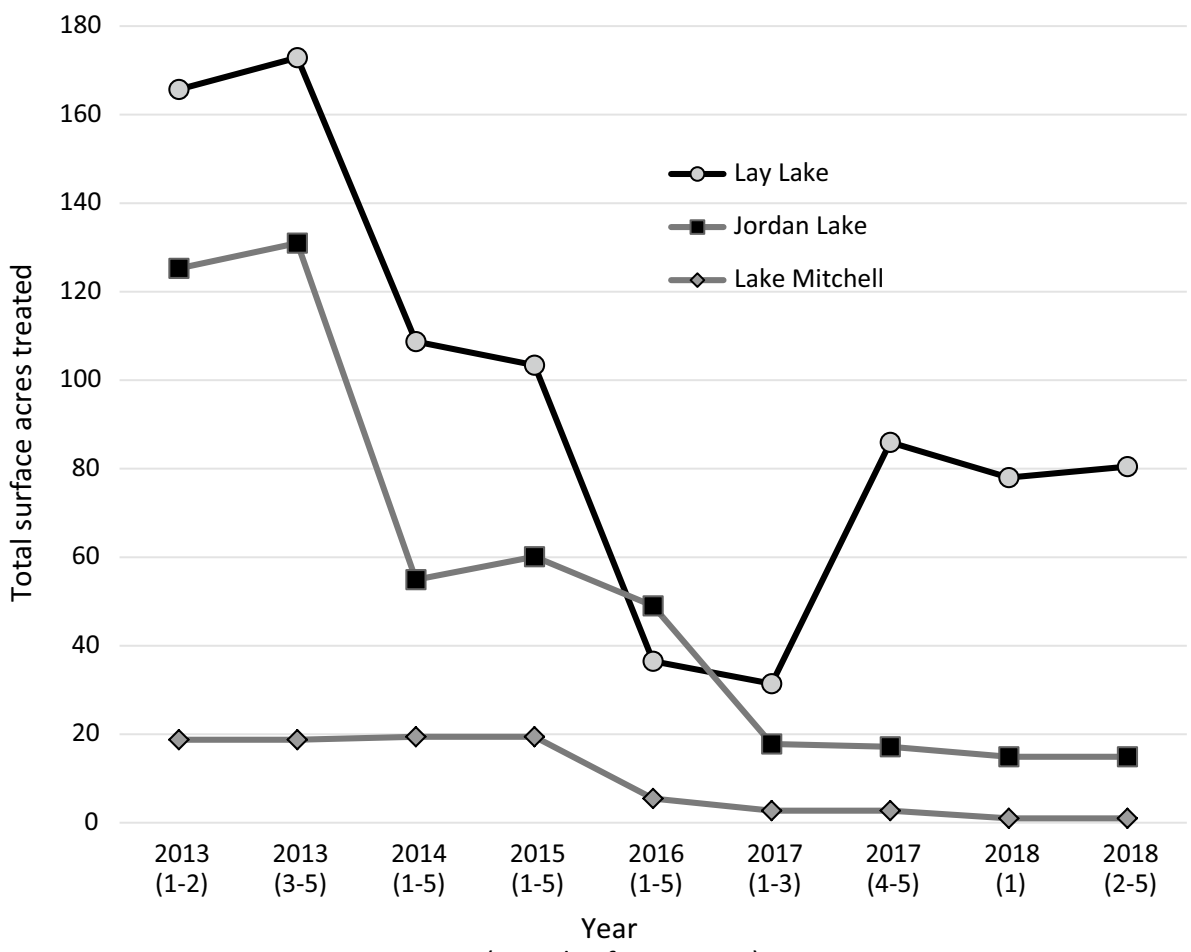

(rounds of treatment)
$88.1 \%$ fewer acres than in 2013. On Lake Mitchell, after 2 years of treatment with Program 5 (2014-2015) treatment acres decreased by $70.9 \%$ to 5.46 total acres in 2016 . Treated acres continued to decrease in 2017 to 2.75 total acres representing an $85.4 \%$ decrease. In 2018 , only one acre required treatment, a $94.7 \%$ decrease from the starting acreage treated in 2013.

In general, there was a positive trend comparing percent of acres receiving Captain XTR treatment with the decrease in number of acres requiring treatment (Fig. 6).
A 1-2 year lag before seeing the acreage decrease was typically observed as it often takes time for thick infestations to be fully controlled and degrade. Linear regression analyses resulted in significant decreases $(\alpha=0.05)$ in continuing acres treated throughout this study period on all reservoirs. Lay Lake $R^{2}=0.89$ and $P=0.005$; Jordan Lake $R^{2}=0.72$ and $P=0.033$; and Lake Mitchell $R^{2}=0.85$ and $P=0.009$. This decrease in acres requiring treatment also closely corresponds to decreases in both algaecide costs and application costs. By aggressively managing to attain
Fig. 6 Percent acres treated with Captain XTR (primary $y$-axis; lines) compared with percent decrease in total treated acres of $L$. wollei (secondary $y$-axis; bars) in three Alabama reservoirs through time

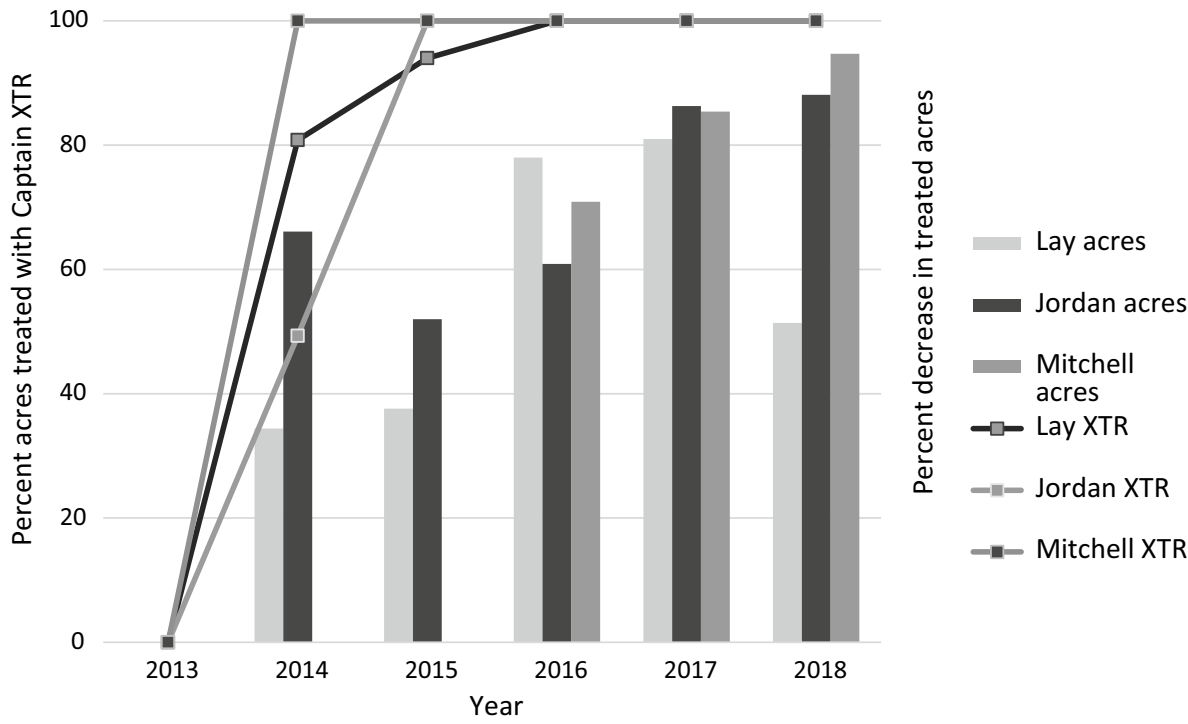


significant reduction in L. wollei biomass to levels that do not require treatment, the long-term program costs have greatly decreased as well as improved program efficiency.

\section{Risk assessment of programs}

Significant research efforts were implemented to ensure the selected treatment programs would continue to support the diverse functions of the reservoir. These were also considered in concert with the negative impacts $L$. wollei infestations had on all use objectives for the reservoir, including aquatic habitat quality and maintenance of water uses by the public. Except for one cove that received a recent treatment, no difference in sediment total copper concentrations was measured in treated and untreated coves in Lay Lake. In situ benthic invertebrate abundance was also not significantly different between treated and untreated coves (Iwinski et al. 2016). Additionally, all treated coves tested have similar or increased survival of Chironomus dilutus and Hyalella azteca in sediment toxicity tests with sampled sediment at different points in time (Calomeni et al. 2015; Iwinski et al. 2016). Short-term laboratory toxicity studies on sentinel aquatic organisms showed that components of Program 1 may have some impact to larval fish or invertebrates (Johnson et al. 2008; Calomeni et al. 2015).

Program 5 showed increased effectiveness on $L$. wollei (and other algae) compared with other copper-based algaecides tested, including some of those previously used in the study reservoirs (Bishop et al. 2018a). Field research with Program 5 in 2013 also supported its effectiveness in applied management programs in these reservoirs (Bishop et al. 2015). Rapid copper sorption has been documented following Captain XTR exposures, including with short contact times (Bishop et al. 2017; Willis et al. 2018). The formulation also results in increased internalized copper into $L$. wollei biomass which is significantly correlated with control (Bishop et al. 2018a) and less likely to desorb back into the water (Bishop et al. 2018b). The ethanolaminechelated copper in the formulation is innately less toxic to nontarget organisms, and the rapid/sustained sorption further decreases copper availability to water-column species (Wagner et al. 2017; Bishop et al. 2018c). There is no water use restrictions following application of Captain XTR (e.g., irrigation, swimming/other recreation, livestock watering, potable source water), and therefore compatible with the diverse use objectives of the reservoirs (SePRO 2014).

Range expansions of $L$. wollei, especially large-scale infestations (Bridgeman and Penamon 2010), coupled with the high potential for ecological impacts (O'neil et al. 2012; Burkholder et al. 2018), human health and economic ramifications (Carmichael and Boyer 2016; Hudon et al. 2014) justify need for management. Risks are innately present with any applied management program, although these should be considered in context of risks of no management (Bishop 2016). Often there is less diversity of aquatic organisms in $L$. wollei infestations compared with native plants as well as less availability of invertebrates to support the food chain due to the habitat alteration (Tourville Poirier et al. 2010; Hudon et al. 2012). Some of the organisms documented in these mats are also not desirable, such as leeches (Annelida, Hirudinea). L. wollei infestations can be inversely related to establishment of native plants and more beneficial algae (Hudon et al. 2014 and references therein). Effective management of $L$. wollei can allow for an increase in beneficial habitat for native organisms (Tourville Poirier et al. 2010).

\section{Management implications}

Management programs using herbicides for invasive aquatic macrophytes have been documented in the literature and outline the intensity of management required to attain significant control (Getsinger et al. 1997; Madsen et al. 2002). However, little data exist on long-term algal management programs using USEPA-registered algaecides. $L$. wollei is a very resilient and adaptable cyanobacterium that is extremely difficult to control. Alabama Power Company has spent a significant amount of time focused on research into $L$. wollei control in these reservoirs and identifying most effective, economically feasible and ecologically appropriate solution for management (Duke 2007; Tedrow 2007; Bishop et al. 2015; Calomeni et al. 2015). Evaluating multiple treatment concepts, novel products/technologies and unique use patterns has helped establish an effective Alabama Power Company treatment program. Large-scale infestations are increasing across the country, especially in the southern, midwest and northeast USA (Hudon et al. 2014; Regan et al. 2017). Information documented from this applied management program can provide guidance to decision makers facing similar questions on overall management approach as well as associated time/cost and effort needed to effectively control $L$. wollei infestations.

Acknowledgements The authors thank Alabama Power Company for providing detailed information used in this research. Authors are grateful for the certified professionals and advanced equipment provided by Aqua Services, Inc. The authors also thank J.T. Gravelie for technical and imagery support.

\section{Compliance with ethical standards}

Conflict of interest The authors declare that they have no conflict of interest.

Ethical approval This article does not contain any studies with human participants or animals performed by any of the authors. 
Open Access This article is distributed under the terms of the Creative Commons Attribution 4.0 International License (http://creativeco mmons.org/licenses/by/4.0/), which permits unrestricted use, distribution, and reproduction in any medium, provided you give appropriate credit to the original author(s) and the source, provide a link to the Creative Commons license, and indicate if changes were made.

\section{References}

Bhadha JH, Lang TA, Alvarez OM, Giurcanu MC, Johnson JV, Odero DC, Daroub SH (2014) Allelopathic effects of Pistia stratiotes (Araceae) and Lyngbya wollei Farlow ex Gomont (Oscillariaceae) on seed germination and root growth. Sustain Agric Res 3:121-130

Bishop WM (2016) A risk-based decision information system for selecting an algal management program (Doctoral dissertation, North Carolina State University)

Bishop WM, Rodgers JH Jr (2011) Responses of Lyngbya magnifica Gardner to an algaecide exposure in the laboratory and field. Ecotoxicol Environ Saf 74:1832-1838

Bishop WM, Rodgers JH Jr (2012) Responses of Lyngbya wollei to exposures of copper-based algaecides: the critical burden concept. Arch Environ Contam Toxicol 62:403-410

Bishop WM, Willis BE, Horton CT (2015) Affinity and efficacy of copper following an algicide exposure: application of the critical burden concept for Lyngbya wollei control in Lay Lake, AL. Environ Manag 55:983-990

Bishop WM, Lynch CL, Willis BE, Cope WG (2017) Copper-based aquatic algaecide adsorption and accumulation kinetics: influence of exposure concentration and duration for controlling the cyanobacterium Lyngbya wollei. Bull Environ Contam Toxicol 99(2):365-371

Bishop WM, Richardson RJ, Willis BE (2018a) Comparison of partitioning and efficacy between copper algaecide formulations: refining the critical burden concept. Water Air Soil Pollut 229(9):300. https://doi.org/10.1007/s11270-018-3958-z

Bishop WM, Villalon G, Willis BE (2018b) Assessing copper adsorption, internalization, and desorption following algaecide application to control Lyngbya wollei from Lake Gaston, NC/VA, USA. Water Air Soil Pollut 229(5):152. https://doi. org/10.1007/s11270-018-3801-6

Bishop WM, Willis BE, Richardson RJ, Cope WG (2018c) The presence of algae mitigates the toxicity of copper-based algaecides to a non-target organism. Environ Toxicol Chem 37(8):2132-2142

Bridgeman TB, Penamon WA (2010) Lyngbya wollei in western Lake Erie. J Great Lakes Res 36(1):167-171

Burkholder JM, Shumway SE, Glibert PM (2018) Food web and ecosystem impacts of harmful algae. In: Shumway SE, Burkholder JM, Morton SL (eds) Harmful algal blooms: a compendium desk reference. Wiley, Hoboken, pp 243-336

Calomeni AJ, Iwinski KJ, Kinley CM, McQueen AD, Rodgers JH $\mathrm{Jr}$ (2015) Responses of Lyngbya wollei to algaecide exposures and a risk characterization associated with their use. Ecotoxicol Environ Saf 116:90-98

Carmichael WW, Boyer GL (2016) Health impacts from cyanobacteria harmful algae blooms: implications for the North American Great Lakes. Harmful Algae 54:194-212

Dibble ED, Kovalenko K (2009) Ecological impact of grass carp. a review of the available data. J Aquat Plant Manag 47:1-15

Duke MB (2007) Laboratory and field responses of target and nontarget species to algaecide exposures. Ph.D. Dissertation, Clemson University, Clemson, SC
Dyck LA (1994) Creation of management strategies that are compatible with the autecology of Lyngbya. Lake Reserv Manag 9:71

Foss AJ, Phlips EJ, Yilmaz M, Chapman A (2012) Characterization of paralytic shellfish toxins from Lyngbya wollei dominated mats collected from two Florida springs. Harmful Algae 16:98-107

Getsinger KD, Turner EG, Madsen JD, Netherland MD (1997) Restoring native vegetation in a Eurasian water-milfoil dominated plant community using the herbicide triclopyr. River Res Appl 13(4):357-375

Hoiczyk E (1998) Structural and biochemical analysis of the sheath of Phormidium uncinatum. J Bacteriol 180:3923-3932

Hudon C, Cattaneo A, Tourville Poirier A-M, Brodeur P, Dumont P, Mailhot Y, Amyot J-P, Despatie S-P, de Lafontaine Y (2012) Oligotrophication from wetland epuration alters the riverine trophic network and carrying capacity for fish. Aquat Sci 74:495-511

Hudon C, De Sève M, Cattaneo A (2014) Increasing occurrence of the benthic filamentous cyanobacterium Lyngbya wollei: a symptom of freshwater ecosystem degradation. Freshw Sci 33(2):606-618

Iwinski KJ, McQueen AD, Kinley CM, Calomeni AJ, Geer TD, Rodgers JH Jr (2016) Sediment copper concentrations, in situ benthic invertebrate abundance, and sediment toxicity: comparison $\mathrm{f}$ treated and untreated coves in a southern reservoir. Water Air Soil Pollut 227:85. https://doi.org/10.1007/s11270-016-2778-2

Johnson BJ, Chao MM, Tedrow OR, McQueen AD, Rodgers JH Jr (2008) Responses of Lepomis macrochirus, Pimephales promelas, Hyalella azteca, Ceriodaphnia dubia, and Daphnia magna to exposures of Algimycin PWF and copper sulfate pentahydrate. J Aquat Plant Manag 46:176-183

Kasinak J-ME, Bishop CJ, Wright RA, Wilson AE (2015) Grass carp do not consume the nuisance benthic cyanobacterium, Lyngbya wollei. J Aquat Plant Manag 53:74-80

Lembi CA (2000) Relative tolerance of mat-forming algae to copper. J Aquat Plant Manag 38:68-70

Madsen JD, Getsinger KD, Stewart RM, Owens CS (2002) Whole lake fluridone treatments for selective control of Eurasian watermilfoil: II. Impacts on submersed plant communities. Lake Reserv Manag 18(3):191-200

Mastin BJ, Rodgers JH Jr (2000) Toxicity and bioavailability of copper herbicides (Clearigate, Cutrine Plus, and copper sulfate) to freshwater animals. Arch Environ Contam Toxicol 39:445-451

Microsoft (2010) Microsoft excel [computer software]. Microsoft Corporation, Redmond, WA

O'Neil JM, Davis TW, Burford MA, Gobler CJ (2012) The rise of harmful cyanobacteria blooms: the potential roles of eutrophication and climate change. Harmful Algae 14:313-334

Paerl HW, Gardner WS, Havens KE, Joyner AR, McCarthy MJJ, Newell SE, Qin B, Scott JT (2016) Mitigating cyanobacterial harmful algal blooms in aquatic ecosystems impacted by climate change and anthropogenic nutrients. Harmful Algae 54:213-222

Regan S, Hoyle ST, Richardson RJ (2017) Lyngbya Distribution and Abundance in selected North Carolina Waterbodies. Poster presentation July 16-19. Aquatic Plant Management Society Annual meeting. Daytona Beach, FL

Reynolds CS (2007) Variability in the provision and function of mucilage in phytoplankton: facultative responses to the environment. Hydrobiologia 578:37-45

SePRO Corporation (2014) Captain XTR algaecide product label. SePRO Corporation Carmel, Anderson, p 46032

Speziale BJ, Dyck LA (1992) Comparative taxonomy of Lyngbya wollei Comb. Nov. (Cyanobacteria). J Phycol 28:693-706

Stauber JL, Florence TM (1987) Mechanism of toxicity of ionic copper and copper complexes to algae. Mar Biol 94:511-519

Straus DL, Tucker CS (1993) Acute toxicity of copper sulfate and chelated copper to channel catfish Ictalarus punctatus. J World Aquac Soc 24:390-395 
Tedrow OR (2007) Responses of problematic cyanobacteria to exposures of copper containing algicides. M.S. Thesis, Clemson University, Clemson, SC

Tien CJ, Sigee DC, White KN (2005) Copper adsorption kinetics of cultured algal cells and freshwater phytoplankton with emphasis on cell surface characteristics. J Appl Phycol 17:379-389

Tourville Poirier AMT, Cattaneo A, Hudon C (2010) Benthic cyanobacteria and filamentous chlorophytes affect macroinvertebrate assemblages in a large fluvial lake. J N Am Benthol Soc 29:737-749

Ullah H, Bishop WM, Whitford B (2015) Pesticidal copper compositions and methods for using the same. US Patent \# 9,137,999

Vijayavel K, Sadowsky MJ, Ferguson JA, Kashian DR (2013) The establishment of the nuisance cyanobacteria Lyngbya wollei in Lake St. Clair and its potential to harbor fecal indicator bacteria. J Great Lakes Res 39(4):560-568
Wagner JL, Townsend AK, Velzis AE, Paul EA (2017) Temperature and toxicity of the copper herbicide (Nautique ${ }^{\mathrm{TM}}$ ) to freshwater fish in field and laboratory trials. Cogent Environ Sci 3:1339386

Willis BE, Pearce M, Bishop WM (2018) Evaluation of copper dissipation, exposure factor and algaecidal efficacy in an irrigation canal following pulse 'slug' application of a chelated copper algaecide (Captain XTR). Appl Water Sci 8:194. https://doi.org/10.1007/ s13201-018-0842-3

Publisher's Note Springer Nature remains neutral with regard to jurisdictional claims in published maps and institutional affiliations. 